\title{
SEM Studies of a Campo del Cielo Meteorite Fall
}

\author{
E. D. Cabanillas*, T. A. Palacios**
}

*CONICET and Departamento de Combustibles Nucleares, Comisión Nacional de Energía Atómica, Avenida del Libertador 8250, 1429 Buenos Aires, Argentina, email: cabanill@ cnea.gov.ar

*** Departamento. de Materiales Comisión Nacional de Energía Atómica.

We have studied a piece belonging to the Campo del Cielo meteorite fall by mean of SEM, EDS, chemical analysis, xrd and optical metallography. The analyses showed that it is an iron hexahedrite meteorite with small inclusions of schreibersite and rhabdite iron-nickel phosphides in a kamacite matrix of approximately $95 \mathrm{wt} . \% \mathrm{Fe}, 5 \mathrm{wt} . \% \mathrm{Ni}$ and $373 \mathrm{ppm}$ of C. We have found Neumann bands differentiated from taenite streaks.

Meteorites are bodies with full of interest. Meteorites alloy are not found naturally on Earth and its phases can not be man made, the processes they are related with involve long time; for example the Widmanstätten pattern is only possible to grow during million of years of cooling, [1][2][3]. This meteorite, of approximately $2 \mathrm{~kg}$ is one of the smaller pieces of the fall, which took place 5000 years ago, in the Chaco Province in Argentine, and it is considered as one of the biggest. Many pieces are at present in situ and others distributed in very important museums around the world.

A slide was cut, polished and etched with Nital 4, then it was xrd analyzed with $\mathrm{Cu} \mathrm{k}_{\text {" }}$ radiation. The surface of this meteorite is smooth without regmaglypts, dark brown and removable. The carbon analyzer exhibited a content in the sample of $373 \pm 19 \mathrm{ppm}$. The EDS determinations of the matrix and inclusions of the meteorite are shown in Table I. The xrd of the internal part shows the following phases: kamacite $(\mathrm{K})$, taenite $(\mathrm{T})$, and magnetite $\left(\mathrm{Fe}_{3} \mathrm{O}_{4}\right)$ with some indications of the existence of: plessite $(\mathrm{K}+\mathrm{T}), \mathrm{Fe} \mathrm{Ni}$, troilite $(\mathrm{SFe})$ daubrelite $\left(\mathrm{FeCr}_{2} \mathrm{~S}_{4}\right)$, schreibersite $(\mathrm{Fe}, \mathrm{Ni})_{3} \mathrm{P}$, and the xrd obtained from the surface: magnetite $\left(\mathrm{Fe}_{3} \mathrm{O}_{4}\right)$, maghemite $\left(\mathrm{Fe}_{2} \mathrm{O}_{3}\right)$, hematite $\left(\mathrm{Fe}_{2} \mathrm{O}_{3}\right)$, and wüstite $(\mathrm{FeO})$. The optical metallography shows the existence of inclusions, subgrain borders and bowed bands, Fig. 1. Also were found corrosion damage along the taenite bands and the existence of little amount of plessite. SEM observations and EDS revealed that the matrix is made up by big grains of kamacite, grooved by thin parallel lines, with a thickness of about $1 \mu \mathrm{m}$ : the as known Neumann lines, Fig. 2, with kamacite composition. Other bowed lines were observed by optical microcopy but after enlarging the SEM image it revealed no uniform thickness and richer in Ni content as the taenite, Figs. 3 and 4.

This meteorite is an iron one, class $\mathrm{H}$ (hexahedrite) because of its composition, and the absence of the Widmanstätten pattern. Other authors refer all the Campo del Cielo fall as octahedrites [4]. The EDS and SEM analysis helped us observe the Taenite plates which are not so regular and parallel as the Neumann ones [4]. The Fe-Ni phosphide schreibersite form, [5] [6], is irregular, see in Fig. 1the particle in the grain border and other near it. The rhabdite, another Fe-Ni phosphide, is of regular pattern, Fig. 3 and 4 and not only was observed by SEM but also by optical microscopy as well.

References.

[1] G. F. Vander Voort, Adv. Mat. and Proc. Feb 2001 37-41.

[2] P. Z. Budka; J. R. M. Viertl and S. V. Thamboo, Ad. Mat. and Proc. 7 27-30.

[3] H. J. Axon "Metallurgy of Meteorites" Progress in Material Science, Vol. 13, Ed. Bruce Chalmers and W. Hume Rothery, Pergamon Press, 1968.

[4] F. Heide and F. Wlotzka,in "Meteorites Messengers from Space", Springer Verlag, chap. 2, p. 103, 1995.

[5] C. R Cortelezzi, E. D. Cabanillas, J. L. Sarutti y R. Torra, II Reunión de Mineralogía y Metalogenia La Plata,4 y 5 julio de 1994. Actas: 449-455. 
[6] R. Cortelezzi, in III Reunión de Mineralogía y Metalogenia. La Plata, agosto de 1996. P. 273.

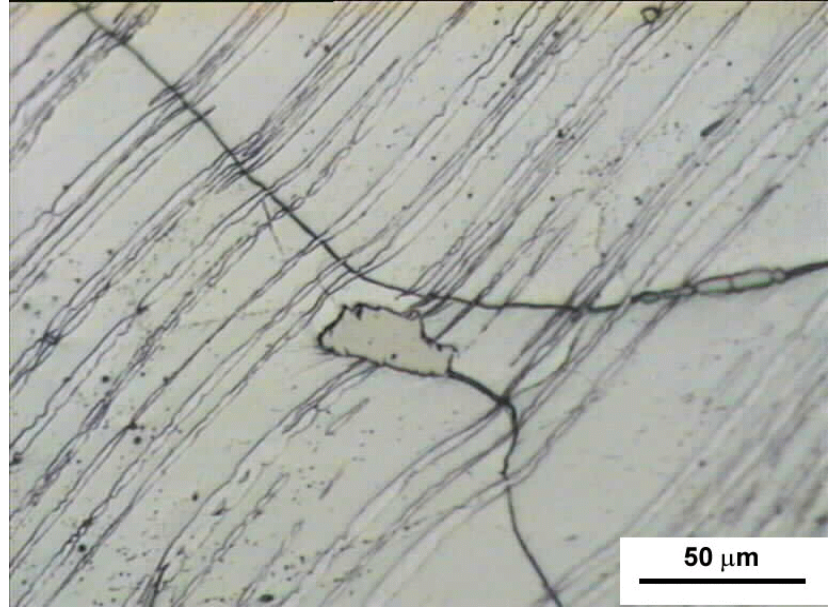

Fig. 1 Schreibersite, border grain, bowed bands

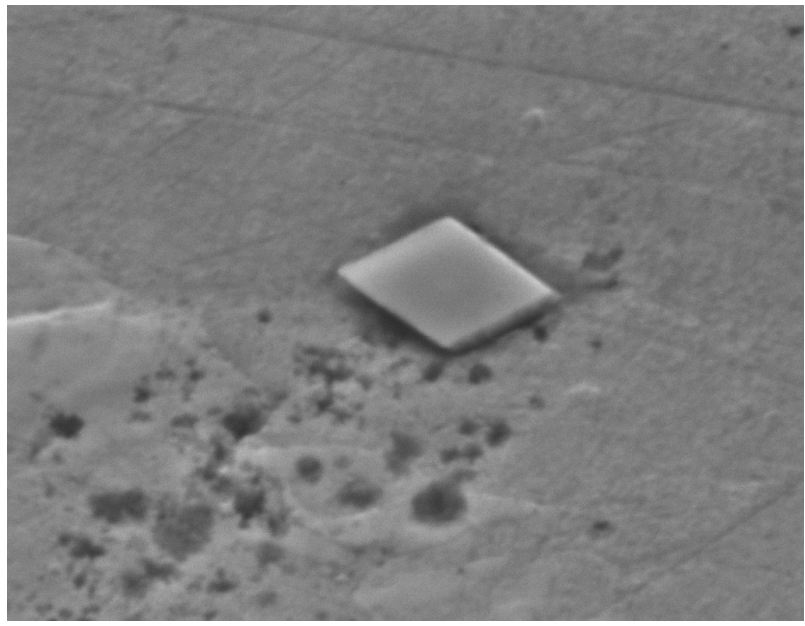

Fig. 4 Rhabdite cross section, aproximately 3: $\mathrm{m}$

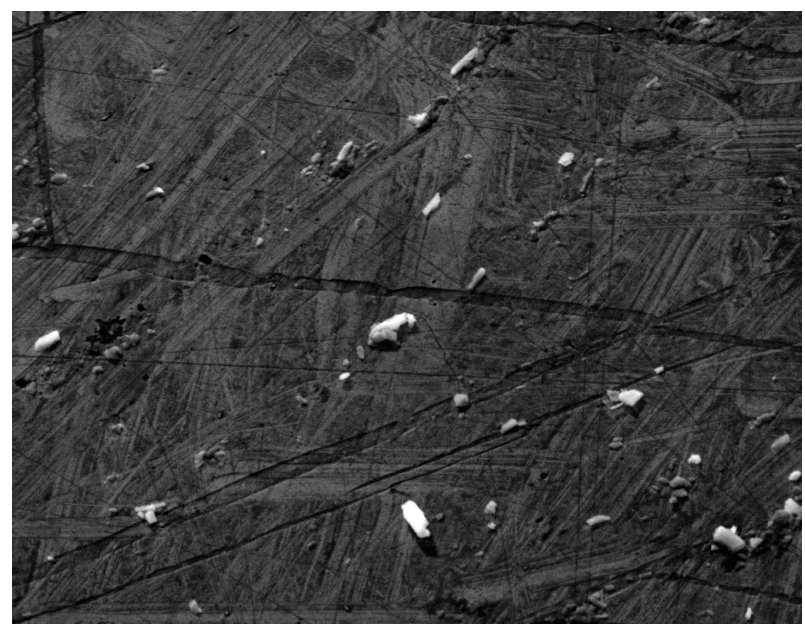

Fig. 2 From left to right, $1: \mathrm{m}$ thick Neumann band, with the same composition as kamacite matrix , $1200 \mathrm{x}$

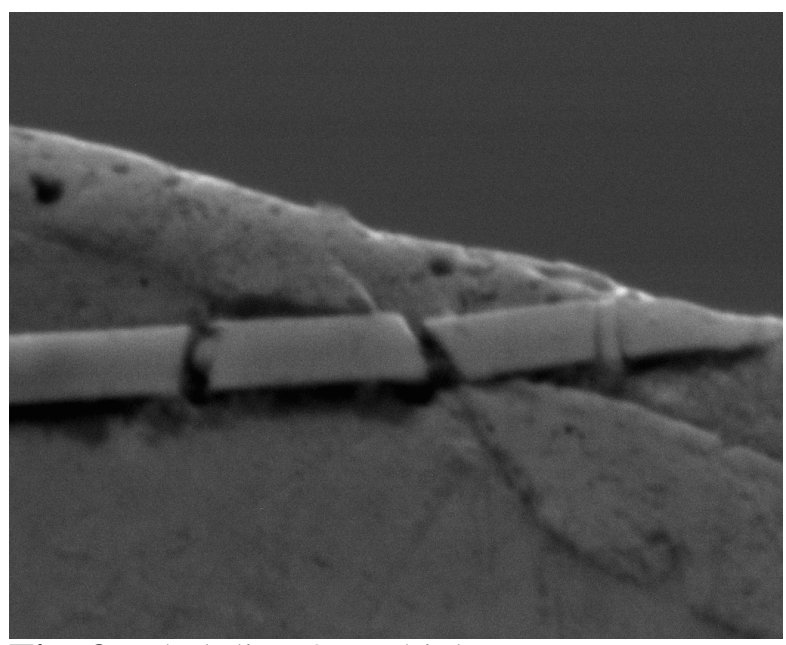

Fig. 3 Rhabdite, 3: $m$ thick.

Table I. Composition of the meteorite

\begin{tabular}{lllll}
\hline \hline & $\mathbf{F e}$ & $\mathbf{N i}$ & $\mathbf{P}$ & $\begin{array}{l}\text { Other } \\
\text { elements. }\end{array}$ \\
\hline Kamacite & $94.6 \pm 0.1$ & $5.4 \pm 0.1$ & - & $\mathrm{C} 370 \pm 19 \mathrm{ppm}$ \\
\hline Taenite & $70 \pm 2$ & $29 \pm 2$ & $0.4 \pm 0.1$ & - \\
\hline Schreibersite & $54 \pm 4$ & $36 \pm 4$ & $5.5 \pm 0.3$ & $\mathrm{Cr}, \mathrm{Si}, \mathrm{S}, \mathrm{Zn}$ \\
\hline Rhabdite & $54 \pm 2$ & $41 \pm 2$ & $4.3 \pm 0.3$ & - \\
\hline \hline
\end{tabular}

